\title{
Results Dynamics of Swimmers-Winners, who Specialize in Breast Stroke Distances at XXV-XXXI Olympic Games
}

\author{
Chernoyarova O. A. \\ Sports Disciplines Department \\ I.Ya. Yakovlev State Pedagogical University \\ Cheboksary, Russia \\ ChernoyarovaOA@Mail.ru
}

\author{
Shuvalova N.V. \\ I.Ya. Yakovlev State Pedagogical University \\ Cheboksary, Russia \\ msta77@yandex.ru
}

\author{
Denisova E.A. \\ I.Ya. Yakovlev State Pedagogical University \\ Cheboksary, Russia \\ gubanova.elena@mail.ru
}

\begin{abstract}
This article contains analysis of the Olympic Games chronicles in swimming. A short historic reference to swimming program is given, particularly in distance using breast stroke for men and women. The analysis of chronicles of the results of the sports swimming national team of USSR and Russia has shown their great achievements in many Olympic Games in general as well as in distance using breast stroke in particular.

The article presents the results analysis of swimmerswinners at breast stroke distances at XXV-XXXI Olympic Games. During the experimental work the following indices were revealed: the average speed, tempo of speed increase among swimmers-winners at breast stroke distances and also the number of gold medals, won by swimmers of different countries at breast stroke distances at XXV-XXXI Olympic Games (men and women).
\end{abstract}

Keywords - sports swimming; the Olympic Games; breast stroke distances (men and women).

\section{INTRODUCTION}

Federal Law [4] "On physical culture and sport in the Russian Federation" pays great attention to the Olympic movement and professional sport development. In recent years the performances of the national teams of the Russian Federation at the Olympic Games in different kinds of sport are thoroughly studied in sports, psychological and pedagogical literature.

\section{LITERATURE REVIEW}

The works of I.L. Ganchar [1], Z.P. Firsov [5], I.P. Nechunaev [2], O.A. Chernoyarova [8] analyze the results of performances among swimmers at the Olympic Games $[6,7]$.
As the Olympic Games chronicle analysis shows, swimming was included into the program of the Ist Olympic Games in 1896, Athens (Greece). However, during the $1^{\text {st }}$ Olympic Games in 1896 in Athens (Greece) and II Olympic Games in 1990 in Paris (France) breast stroke distance wasn't included into the program of competitions.

During III Olympic Games in 1904 in Saint Louis (the USA) distances were transformed into yards (1yard $=91 \mathrm{~cm}$ $44 \mathrm{~mm})$. The program included 440 yards breast stroke distance (men). During the IV Olympic Games in 1908 in London (Great Britain) in accordance with FINA decision 440 yards $(402,5 \mathrm{~m})$ breast stroke distance (men) was replaced by 200 meters breast stroke distance (men).

During V Olympic Games in 1912 in Stockholm (Sweden) 400 meters breast stroke distance (men) was added into the program.

During VII Olympic Games in 1920 in Antwerp (Belgium) the program of competitions in swimming at breast stroke distances didn't change $(200,400 \mathrm{~m}$ breast stroke).

During VIII Olympic Games in 1924 in Paris (France) 400 meters breast stroke distance (men) was excluded from the program and for the first time 200 meters breast stroke distance (women) was included.

It should be noted that starting from VIII Olympic Games in 1924 in Paris (France) till XVIII Olympic Games in 1964 in Tokyo (Japan) there were no changes in swimming program of competitions, men and women compete only at 200 meters breast stroke distance. 
3. Methods of mathematical statistics.

During XIX Olympic Games in 1986 in Mexico City (Mexico) for the $1^{\text {st }}$ time 100 meters breast stroke distance was included into the program both for men and women.

Thus, starting from XIX Olympic Games in 1968 in Mexico City (Mexico) till XXXI Olympic Games in 2016 in Rio de Janeiro (Brazil) the program of competitions in swimming didn't change.

The most titled swimmer, who specializes in breast stroke swimming, became Kosuke Kitajima (Japan). He is four times Olympic champion in 2004, 2008 at 100, 200 meters breast stroke distances.

\section{RESEARCH METHODOLOGY}

Results chronicle analysis of the national team of the USSR and Russia in swimming shows that our athletes achieved success at many Olympic Games, including breast stroke distances.

At the same time, scientific, pedagogical and methodical literature analysis shows that the information presented by the authors is not always precise and there is always need for statistical information renewal in order to define the dynamics of the results among swimmers at the Olympic Games.

The problem of the research: What is the results dynamics among swimmers-winners, who specialize in breast stroke distances at XXV-XXXI Olympic Games?

The aim of the research is to reveal the peculiarities of results dynamics among swimmers-winners, who specialize in breast stroke distances at XXV-XXXI Olympic Games.

The object of the research: a long-term training process of swimmers.

The subject of the research: results dynamics of performances among swimmers-winners, who specialize in breast stroke distances at XXV-XXXI Olympic Games.

In accordance with the aim we defined the following objectives of the research:

1. To gather information about the results among swimmers-winners at breast stroke distances at XXV-XXXI Olympic Games (men and women).

2. To define the average speed of swimmers-winners at breast stroke distances at XXV-XXXI Olympic Games (men and women).

3. To analyze rates of speed increase among swimmers-winners at breast stroke distances at XXV-XXXI Olympic Games (men and women).

4. To reveal the amount of gold medals, won by swimmers of different countries at breast stroke distances at XXV-XXXI Olympic Games (men and women).

Research methods:

1. Scientific, methodical, encyclopedic literature and electronic resource on the research problem analysis.

2. Comparative analysis of protocols, competitions results tables among the strongest national teams of the World and Russia in swimming at breast stroke distances at XXV-XXXI Olympic Games.

\section{RESULTS}

Practical importance is in the fact that the received information helps to master more precise information concerning "Theory and methodology of swimming" discipline, which is studied by students from physical culture department, retraining and qualification improvement courses participants.

This article is presented on the basis of Olympiads results thorough analysis [3].

During the theoretic research we gathered information concerning the results of swimmers-winners at breast stroke distances at XXV-XXXI Olympic Games (men and women) (table 1,2).

TABLE I. THE RESULTS OF SWIMMERS-WINNERS AT BREAST

STROKE DISTANCES AT XXV-XXXI OLYMPIC GAMES (MEN)

\begin{tabular}{|c|c|c|}
\hline Distances & \multirow{2}{*}{$\begin{array}{c}100 \text { breast } \\
\text { stroke }\end{array}$} & $\begin{array}{c}200 \text { breast } \\
\text { stroke }\end{array}$ \\
\cline { 1 - 1 } Olympiads (date) & $1.01,50$ & $2.10,16$ \\
\hline Olympiad -1996 Atlanta (the USA) & $1.00,65$ & $2,12,57$ \\
\hline Olympiad -2000 Sidney (Australia) & $1.00,46$ & $2.10,87$ \\
\hline Olympiad -2004 Athens (Greece) & $1.00,08$ & $2.09,44$ \\
\hline $\begin{array}{c}\text { Olympiad -2008 Beijing (China) } \\
\text { Olympiad -2012 London (Great } \\
\text { Britain) }\end{array}$ & 58,91 & $2.07,64$ \\
\hline $\begin{array}{c}\text { Olympiad -2016 Rio de Janeiro } \\
\text { (Brazil) }\end{array}$ & 58,46 & $2.07,28$ \\
\hline
\end{tabular}

TABLE II. THE RESULTS OF SWIMMERS-WINNERS AT BREAST STROKE DISTANCES AT XXV-XXXI OLYMPIC GAMES (WOMEN)

\begin{tabular}{|c|c|c|}
\hline Distances & $\begin{array}{c}100 \text { breast } \\
\text { stroke }\end{array}$ & $\begin{array}{c}200 \text { breast } \\
\text { stroke }\end{array}$ \\
\hline Olympiads (date) & $1.08,00$ & $2.26,65$ \\
\hline Olympiad -1992 Barcelona (Spain) & $1.07,73$ & $2.25,41$ \\
\hline Olympiad -2000 Sidney (Australia) & $1.07,05$ & $2.24,35$ \\
\hline Olympiad -2004 Athens (Greece) & $1.06,64$ & $2.23,37$ \\
\hline $\begin{array}{c}\text { Olympiad -2008 Beijing (China) } \\
\text { Olympiad -2012 London (Great } \\
\text { Britain) }\end{array}$ & $1.05,17$ & $2.20,22$ \\
\hline $\begin{array}{c}\text { Olympiad -2016 Rio de Janeiro } \\
\text { (Brazil) }\end{array}$ & $1.05,47$ & $2.19,59$ \\
\hline
\end{tabular}

Then we defined the average speed of swimmers-winners at 100, 200 meters breast stroke distance during XXV-XXXI Olympic Games (men and women). Pictures 1-4 present the results. 


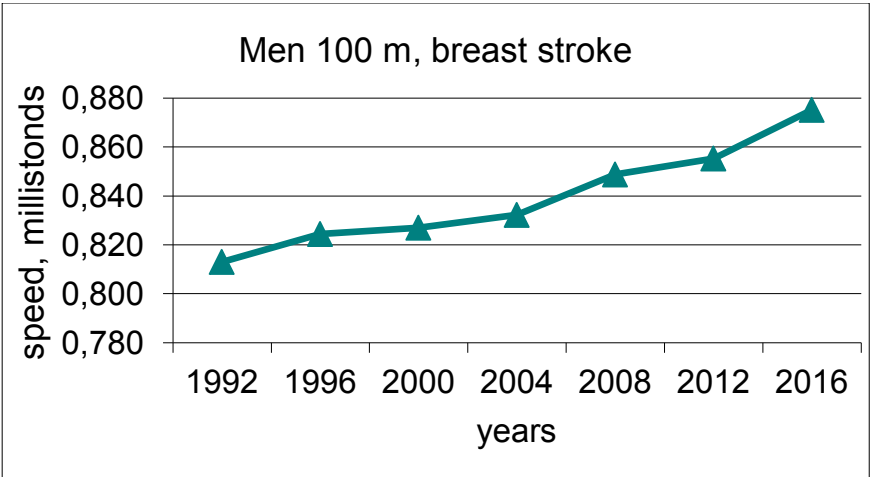

Fig. 1. The average speed of swimmers-winners at 100 meters breast stroke distance during XXV-XXXI Olympic Games (men)

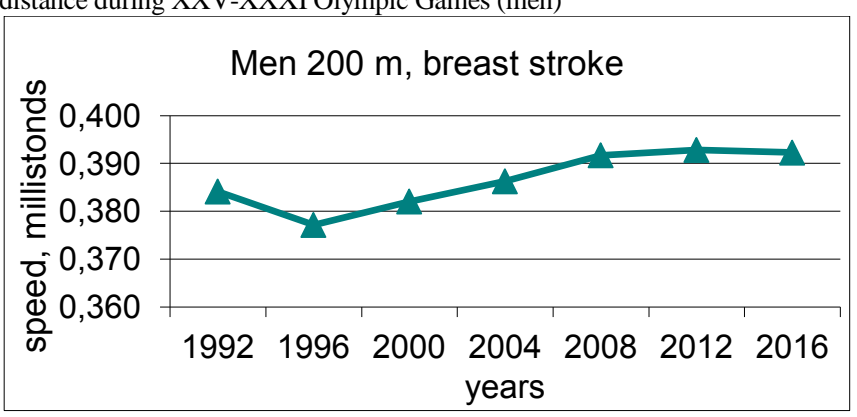

Fig. 2. The average speed of swimmers-winners at 200 meters breast stroke distance during XXV-XXXI Olympic Games (men)

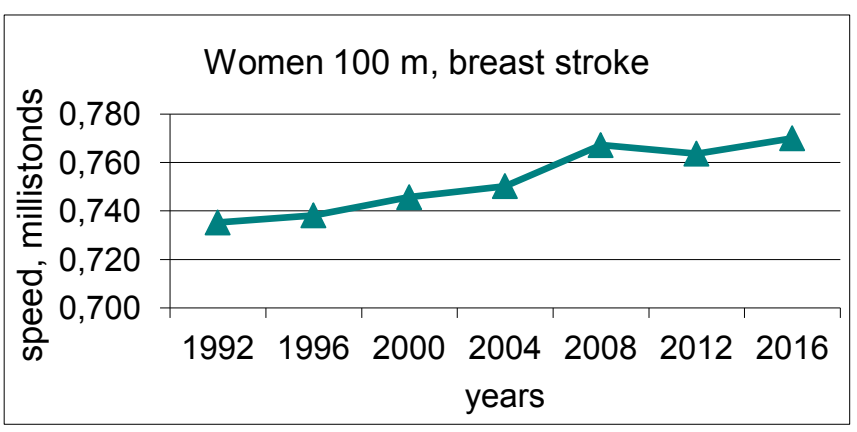

Fig. 3. The average speed of swimmers-winners at 100 meters breast stroke distance during XXV-XXXI Olympic Games (women)

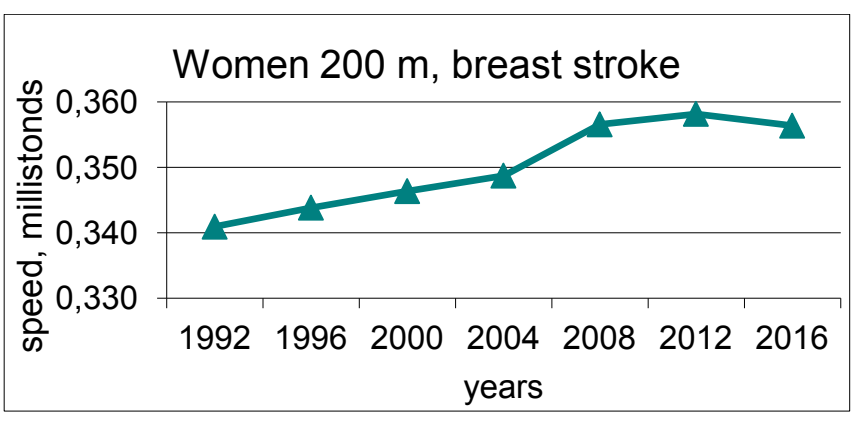

Fig. 4. The average speed of swimmers-winners at 200 meters breast stroke distance during XXV-XXXI Olympic Games (women)

The average speed among men at 100 meters breast stroke distance at Olympiad -1992 was $0,813 \mathrm{~m} / \mathrm{s}$, at Olympiad -2016 the average speed was $0,875 \mathrm{~m} / \mathrm{s}$.
The average speed among men at 200 meters breast stroke distance at Olympiad -1992 was $0,384 \mathrm{~m} / \mathrm{s}$, at Olympiad -2016 the average speed was $0,392 \mathrm{~m} / \mathrm{s}$.

The average speed among women at 100 meters breast stroke distance at Olympiad -1992 was $0,735 \mathrm{~m} / \mathrm{s}$, at Olympiad -2016 the average speed was $0,770 \mathrm{~m} / \mathrm{s}$.

The average speed among women at 200 meters breast stroke distance at Olympiad -1992 was 0,341 m/s, at Olympiad -2016 the average speed was $0,356 \mathrm{~m} / \mathrm{s}$.

At the final stage of the research we revealed the number of gold medals, won by the swimmers of different countries in individual kinds of programs $(100,200$ meters breast stroke distance) at Olympiads 1992-2016 (men and women) (table 3,4).

TABLE III. NUMBER OF GOLD MEDALS, WON BY SWIMMERSWINNERS AT BREAST STROKE DISTANCES DURING XXV-XXXI

\begin{tabular}{|c|c|c|c|c|c|c|c|}
\hline \multicolumn{1}{|c|}{ OLYMPIC GAMES (MEN) } \\
$\begin{array}{c}\text { iad } \\
\text { Distan } \\
\text { ce }\end{array}$ & $\begin{array}{c}1992 \\
\text { Barcel } \\
\text { ona }\end{array}$ & $\begin{array}{c}1996 \\
\text { Atlant } \\
\text { a }\end{array}$ & $\begin{array}{c}2000 \\
\text { Sidn } \\
\text { ey }\end{array}$ & $\begin{array}{c}2004 \\
\text { Gree } \\
\text { ce }\end{array}$ & $\begin{array}{c}2008 \\
\text { Beiji } \\
\text { ng }\end{array}$ & $\begin{array}{c}2012 \\
\text { Lond } \\
\text { on }\end{array}$ & $\begin{array}{c}2016 \\
\text { Rio de } \\
\text { Janeiro }\end{array}$ \\
\hline 100 & USA & $\begin{array}{c}\text { Belgi } \\
\text { um }\end{array}$ & Italy & $\begin{array}{c}\text { Japa } \\
\text { n }\end{array}$ & $\begin{array}{c}\text { Japa } \\
\text { n }\end{array}$ & RSA & $\begin{array}{c}\text { Great } \\
\text { Britain }\end{array}$ \\
\hline 200 & USA & $\begin{array}{c}\text { Hung } \\
\text { ary }\end{array}$ & Italy & $\begin{array}{c}\text { Japa } \\
\text { n }\end{array}$ & $\begin{array}{c}\text { Japa } \\
\text { n }\end{array}$ & $\begin{array}{c}\text { Hung } \\
\text { ary }\end{array}$ & $\begin{array}{c}\text { Kazakhs } \\
\text { tan }\end{array}$ \\
\hline
\end{tabular}

TABLE IV. NUMBER OF GOLD MEDALS, WON BY SWIMMERSWINNERS AT BREAST STROKE DISTANCES DURING XXV-XXXI

\begin{tabular}{|c|c|c|c|c|c|c|c|}
\hline \multicolumn{8}{|c|}{ OLYMPIC GAMES (WOMEN) } \\
\hline Olymp & 1992 & 1996 & 2000 & 2004 & 2008 & 2012 & 2016 \\
\hline & Barcel & Atlan & Sidne & Gree & Beijin & Londo & Rio \\
\hline Distan & ona & ta & $\mathrm{y}$ & ce & $\mathrm{g}$ & $\mathrm{n}$ & de \\
\hline ce & & & & & & & $\begin{array}{l}\text { Janei } \\
\text { ro }\end{array}$ \\
\hline 100 & CIS & RSA & USA & Chin & Austra & Lithua & USA \\
\hline 200 & Japan & RSA & $\begin{array}{c}\text { Hung } \\
\text { ary }\end{array}$ & USA & USA & USA & $\begin{array}{c}\text { Japa } \\
\text { n }\end{array}$ \\
\hline
\end{tabular}

\section{CONCLUSION}

Thus, the analysis showed that the results of swimmerswinners at Olympiads (1992-2016) among men were the following:

At 100meters breast stroke distance the result improved for 4,37 seconds and the average tempo of increase was $2,3 \%$.

At 200meters breast stroke distance the result improved for 2,70 seconds and the average tempo of increase was $2,6 \%$.

The analysis showed that the results of swimmerswinners at Olympiads (1992-2016) among women were the following:

At 100meters breast stroke distance the result improved for 3,07 seconds and the average tempo of increase was $2,6 \%$.

At 200meters breast stroke distance the result improved for 6,35 seconds and the average tempo of increase was 
The national teams of Belgium, Great Britain,

\section{$3,1 \%$ (picture 5).}

The greatest speed increase among women at 200 meters breast stroke distance was $3,1 \%$, and the lowest speed increase among men at 100 meters breast stroke distance was $2,3 \%$. At 200 meters breast stroke distance among men and at 100 meters breast stroke distance amon women speed increase was the same- $2,6 \%$.

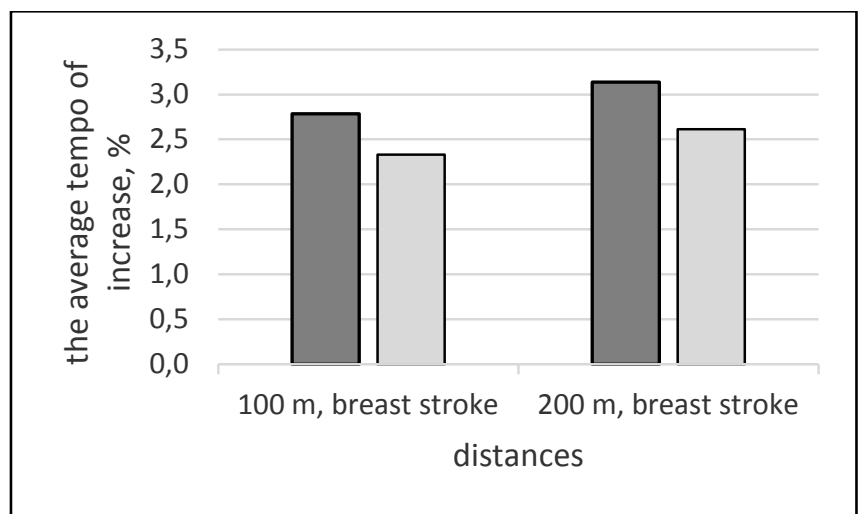

Fig. 5. Speed increase among swimmers-winners at 100 and 200 meters breast stroke distance during XXV-XXXI Olympic Games (men and women)

Performances results analysis helped to define the number of gold medals, won by different countries at 100 , 200 meters breast stroke distances (men and women) at Olympiad 1992-2016 (picture 6).

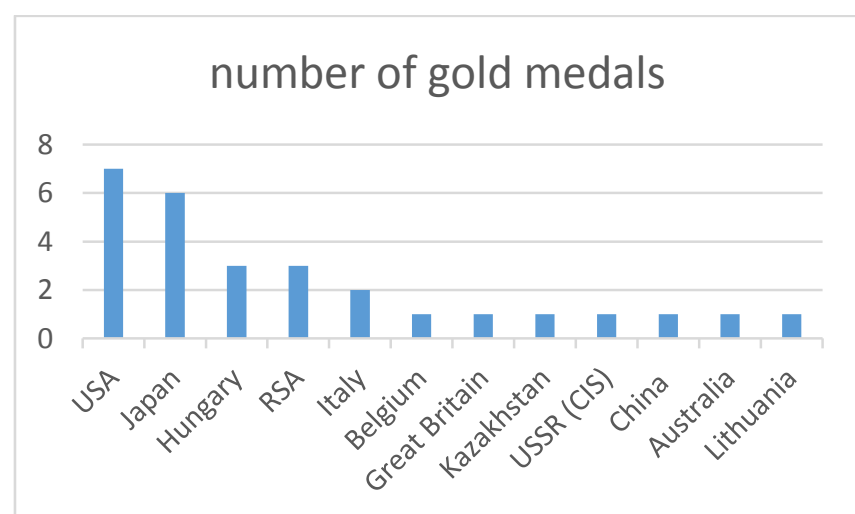

Fig. 6. Number of gold medals, won by swimmers-winners at 100, 200 meters breast stroke distances during Olympiads 1992-2016

Thus, the number of gold medals at 100, 200 meters breast stroke distances at Olympiads 1992-2016, won by different countries in individual performances of the program (men and women) are the following:

the national team of the USA has 7 gold medals.

the national team of Japan has 6 gold medals.

The national team of Hungary and the national team of RSA have 3 gold medals.

The national team of Italy has 2 gold medals.
Kazakhstan, CIS (Russia), China, Australia, Lithuania have 1 gold medal each.

\section{References}

[1] Ganchar I. L. Theory and methodology of teaching swimming: textbook. Minsk: Four quarters; Ecoprospective. 1998, 352.

[2] Nechunaev I. P. Book-coach. Moscow : Eksmo. 2012, 272.

[3] The results of Olympiads. URL: http://www.olympiady.ru

[4] Federal Law "On physical culture and sport in the Russian Federation" 26.06.2007 N 118-FZ.

[5] Firsov Z. P. Swimming : Reference-book. - Moscow : Physical culture and sport. 1976, 383.

[6] Zinaida M. Kuznetsova, Yriy D. Ovchinnikov. Fatigue is a biomechanical category. The Russian Journal of Physical Education and Sport. 2018, vol. 13(1), pp. 134-138. DOI: 10/14526/01_2018_298

[7] Alexsandr S. Kuznetsov. Russian Professor's meeting. Russian Journal of Physical Education and Sport. 2019, 14(1), pp. 17-22. DOI: 10.14526/2070-4798-2019-14-1-18-24

[8] Chernoyarova O. A. Swimming : manual. - the $3^{\text {rd }}$ edition, added. Cheboksary : Chuvash State Pedagogical University. 2019, 307. 